\title{
Immunometabolic status and productive performance differences between periparturient Simmental and Holstein dairy cows in response to pegbovigrastim
}

\author{
V. Lopreiato, ${ }^{1,2}$ A. Minuti, ${ }^{2 *}$ F. Trimboli, ${ }^{1}$ D. Britti, ${ }^{1}$ V. M. Morittu, ${ }^{1}$ F. Piccioli Cappelli, ${ }^{2}$ J. J. Loor, ${ }^{3}$ and E. Trevisi ${ }^{2}$ \\ ${ }^{1}$ Interdepartmental Services Centre of Veterinary for Human and Animal Health, Department of Health Science, Magna Græcia University, \\ 88100 Catanzaro, Italy \\ ${ }^{2}$ Department of Animal Sciences, Food and Nutrition, Faculty of Agriculture, Food and Environmental Science, \\ Università Cattolica del Sacro Cuore, 29122 Piacenza, Italy \\ ${ }^{3}$ Department of Animal Sciences and Division of Nutritional Sciences, University of Illinois, Urbana 61801
}

\section{ABSTRACT}

In the present study, we aimed to investigate the side effects of pegbovigrastim, injected approximately $7 \mathrm{~d}$ before parturition and on the day of calving, on a panel of plasma biomarkers to evaluate energy, inflammatory, oxidative, and liver function status. We also addressed treatment responses in different breeds during the transition period. Holstein and Simmental cows were randomly assigned into 2 groups based on expected calving date and according to parity: the treated group (PEG; 14 Holstein and 12 Simmental cows) received pegylated recombinant bovine granulocyte colony stimulating factor (pegbovigrastim, Imrestor; Elanco Animal Health, Greenfield, IN), and the control group (CTR; 14 Holstein and 14 Simmental cows) received saline solution. The PEG or CTR treatments were administered via subcutaneous injection in the scapular region at approximately $7 \mathrm{~d}$ (mean $7.80 \pm 5.50 \mathrm{~d}$ ) before expected parturition and within $24 \mathrm{~h}$ after calving. Blood samples were collected at $-21,-7$ (before injection), 1,3 , and $28 \mathrm{~d}$ relative to calving. Milk production was recorded at $7,15,21,30$, and $42 \mathrm{~d}$. A mixed model with repeated measures was fitted to the normalized data using Proc MIXED of SAS (SAS Institute Inc., Cary, NC). Simmental PEG cows showed higher plasma protein concentrations at 1 and $3 \mathrm{~d}$ after calving compared with Simmental CTR and Holstein PEG cows, whereas no differences were detected between Holstein PEG and CTR cows. Albumin was greater at $1 \mathrm{~d}$ in Simmental PEG compared with Simmental CTR cows. In contrast, $\gamma$-glutamyl transferase was higher overall (across breed) in PEG than in CTR. The PEG group had higher values throughout the postcalving period compared with CTR. Cows treated with pegbovigrastim had also

Received January 17, 2019.

Accepted June 5, 2019.

*Corresponding author: andrea.minuti@unicatt.it higher alkaline phosphatase (ALP) activity at 1 and 3 $\mathrm{d}$ after calving. The Holstein PEG group had higher ALP activity at $3 \mathrm{~d}$ compared with the Holstein CTR and Simmental PEG groups, and higher ALP at $1 \mathrm{~d}$ compared with the Simmental CTR group. The PEG group had higher levels of IL- 6 at 3 and $28 \mathrm{~d}$ but higher IL-1 $\beta$ only at $28 \mathrm{~d}$ after calving compared with the CTR group. Overall, Holstein cows were characterized by a greater response in the production of inflammation biomarkers (cytokines, haptoglobin, and ceruloplasmin). In addition, PEG cows had higher values of zinc at 1 and $3 \mathrm{~d}$ after calving compared with CTR cows. The response observed in plasma biomarkers for energy metabolism and liver functionality after pegbovigrastim treatment in Simmental and Holstein cows was not different from that in control cows. However, our data shed light on the different metabolic adaptations during the transition period between Simmental and Holstein cows, characterized by different energy, inflammatory, and oxidative pattern responses. For the first time, we have highlighted the effect of pegbovigrastim in maintaining stable cytokine levels during the first month after parturition, reflecting greater regulation of neutrophil recruitment, trafficking, and maturation during the inflammatory response. These results provide evidence of the immunomodulatory action of pegbovigrastim around parturition, when dairy cows are highly immunosuppressed. At the same time, these data demonstrate that increasing release of cytokines after parturition is not linked to exacerbation of a systemic inflammation evaluated based on haptoglobin and ceruloplasmin levels.

Key words: immunometabolism, pegbovigrastim, Simmental, transition period

\section{INTRODUCTION}

High-yielding dairy cows are subjected to many challenges during the transition period, requiring an 
effective immune adaptive response (Grummer, 1995; Trevisi et al., 2012a; Trevisi and Minuti, 2018). These challenges encompass several infectious and metabolic disorders (e.g., ketosis, uterine infections, mastitis) that compromise animal welfare (Duffield et al., 2009; Dubuc et al., 2010). In addition, parturition leads to a systemic inflammatory state characterized by changes in concentrations of positive and negative acute-phase proteins (Bionaz et al., 2007; Trevisi et al., 2013, 2015). One of the major reasons for poor success in overcoming parturition-related disorders is the decreased immune cell function around calving time (Kehrli et al., 1989; Kimura et al., 2014).

The negative energy balance during the transition period explains this reduced immune function, which is also associated with increased concentrations of some blood metabolites as a result of tissue mobilization (Kehrli et al., 1989; Ingvartsen and Moyes, 2013). Indeed, PMN and lymphocyte functions decrease gradually, starting about 2 wk before calving, with the lowest efficiencies between the time of calving and $2 \mathrm{~d}$ after (Kehrli et al., 1989; Batistel et al., 2018). According to Kehrli et al. (1989), the impaired neutrophil function during the periparturient period can be attributed to many of the hormonal and metabolic changes that prepare the mammary gland for lactation. Around this critical period, metabolism shifts from the demands of pregnancy to those of lactation, increasing demands for energy and protein. Together, these metabolic and immunologic challenges during the peripartal period are important factors that limit the ability of most cows to achieve optimal performance and immune-metabolic status (Drackley, 1999; Loor et al., 2013).

To directly improve immune efficiencies around parturition and reduce the risk of clinical mastitis in periparturient dairy cows and heifers during the first month following calving, a recombinant bovine granulocyte colony-stimulating factor (rbG-CSF; pegbovigrastim, Imrestor, Elanco Animal Health, Greenfield, IN) has been commercially released. Granulocyte colony-stimulating factor is produced by a variety of cells including monocytes, macrophages, and cells of mesodermal origin, including vascular endothelial cells, fibroblasts, and keratinocytes (Kehrli et al., 1991; Nagata and Fukunaga, 1991). It induces differentiation of progenitor cells into mature neutrophils, shortens maturation time within the bone marrow, and alters functionality by increasing phagocytosis and antibody-dependent cellmediated cytotoxicity and priming oxidation (Hercus et al., 2009).

Common outcomes in previous and recent studies included a large increase in PMN number, improved ingestion of bacteria, and improved cytotoxicity by PMN after pegbovigrastim injections at around $7 \mathrm{~d}$ before calving (first injection) and at calving (second injection; Kimura et al., 2014; McDougall et al., 2017; Zinicola et al., 2018). Furthermore, an investigation in Mexican dairy herds by Ruiz et al. (2017) concluded that pegbovigrastim can help dairy cows face immune periparturient disorders such as the incidence of mastitis and the occurrence of retained placenta and metritis. However, these latter studies primarily investigated hematological responses, PMN function (such as phagocytosis, oxidative burst, and myeloperoxidase release), immune-related disorders (clinical mastitis, retained placenta, and clinical metritis), and only a few biomarkers in plasma, such as FFA and BHB that are directly affected by feed intake and health status.

In this study, we aimed to investigate the effects of pegbovigrastim, injected approximately $7 \mathrm{~d}$ before parturition and on the day of calving, on a wide panel of plasma biomarkers to allow a full evaluation of energy, inflammatory, oxidative, and liver function status. Furthermore, because cows of different breeds - highly specialized in milk production or not-show different inflammatory responses during the periparturient period (Curone et al., 2018), we hypothesized that the response after administration of pegbovigrastim would differ between cows highly specialized for milk production (Holstein breed) and dual-purpose cows selected for both meat and milk production (Simmental breed).

\section{MATERIALS AND METHODS}

\section{Animal Management and Treatment}

The experimental design of this study involved Simmental and Holstein cows (total $\mathrm{n}=54$ ) enrolled on 2 farms. The trial was carried out in accordance with Italian laws on animal experimentation (DL n. 26, 04/03/2014) and ethics (Authorization of Italian Health Ministry N 403/2017-PR). On both farms, dry cows were housed in a free-walking straw barn; after parturition, Holstein cows were moved to a cubicle freestall barn, whereas Simmental cows were moved to a lactation barn with a free-walking straw system. The management procedures throughout the experiment were similar on both farms, according to the protocol for this study: cows were fed a TMR once daily (0700 and $0800 \mathrm{~h}$, lactating and dry cows respectively), and after parturition they were milked twice daily (at 0500 and $1700 \mathrm{~h}$ ). Diet compositions used in the close-up and early lactation period are reported in Table 1. Once enrolled in the study, cows were randomly assigned to 2 groups based on expected calving date and parity: the treated group (PEG; 14 Holstein and 12 Simmental cows) received rbG-CSF (pegbovigrastim; Imrestor; Elanco Animal Health), and the control group (CTR; 
14 Holstein and 14 Simmental cows) received saline solution.

Treatments were administered via subcutaneous injection in the scapular region using prefilled syringes, provided by the manufacturer, for the PEG group (15 $\mathrm{mg}$ of pegbovigrastim in $2.7 \mathrm{~mL}$ of solution) and syringes with 18 -gauge $\times 2.5-\mathrm{cm}$ needles for the CTR group ( $2.7 \mathrm{~mL}$ of sterile saline). The first dose was administered at approximately $7 \mathrm{~d}$ (on average, $7.80 \pm$ $5.50 \mathrm{~d}$ ) before expected parturition, depending on the judgment of investigators, based on physical changes including swelling of vulva and filling of udder. The second dose was administered within $24 \mathrm{~h}$ after calving.

\section{Blood Sample Collection and Biomarker Analysis}

Blood samples were obtained before TMR was delivered in the morning at $-21,-7$ (before treatment injections), 1, 3, and 28 d relative to parturition. Blood samples were collected from the jugular vein using an 18-gauge Vacutest Kima needle (Vacutest Kima srl, Arzergrande, Italy) into 9-mL evacuated test tubes
(Vacutest Kima srl) containing lithium heparin, and immediately cooled in an ice-water bath. After collection, blood samples were centrifuged at $1,900 \times g$ for 16 min at $4^{\circ} \mathrm{C}$. Plasma obtained was aliquoted and stored at $-20^{\circ} \mathrm{C}$ until metabolite analysis. Plasma metabolites were analyzed at $37^{\circ} \mathrm{C}$ by using an automated clinical analyzer (ILAB 650, Instrumentation Laboratory Company, Lexington, MA). Commercial kits were used to measure glucose, total cholesterol, triglycerides, urea, calcium, inorganic phosphorus, magnesium, total protein, albumin, total bilirubin, and creatinine (Instrumentation Laboratory SpA, Milan, Italy), nonesterified (free) fatty acids (FFA), alkaline phosphatase (ALP), and zinc (Wako, Chemicals GmbH, Neuss, Germany), and BHB (kit Ranbut, Randox Laboratories Ltd., Crumlin, UK). Electrolytes $\left(\mathrm{Na}^{+}, \mathrm{K}^{+}\right.$, and $\left.\mathrm{Cl}^{-}\right)$were detected by the potentiometer method (ion selective electrode connected to ILAB 650). Kinetic analysis was adopted to determine the activity of enzymes: aspartate aminotransferase (AST, EC 2.6.1.1) and $\gamma$-glutamyl transferase (GGT, EC 2.3.2.2), using commercial kits (Instrumentation Laboratory SpA, Milan, Italy). The

Table 1. Ingredient and nutrient composition (\% of DM unless otherwise noted) of close-up (from -21 to parturition) and early lactation (from parturition to 30 DIM) diets for Holstein and Simmental dairy cows treated with pegbovigrastim (PEG) or with saline (CTR) at approximately $\mathrm{d}-7$ relative to calving and on the day of calving within $24 \mathrm{~h}$

\begin{tabular}{|c|c|c|c|c|}
\hline \multirow[b]{2}{*}{ Item } & \multicolumn{2}{|c|}{ Holstein } & \multicolumn{2}{|c|}{ Simmental } \\
\hline & Close-up & Lactation & Close-up & Lactation \\
\hline \multicolumn{5}{|l|}{ Ingredient } \\
\hline Corn silage & - & 34.70 & - & - \\
\hline Alfalfa haylage & - & 4.63 & - & - \\
\hline Alfalfa hay, first cut & - & 4.02 & - & - \\
\hline Alfalfa hay, second or later cuts & - & 4.02 & - & 25.00 \\
\hline Grass hay & 50.24 & 3.93 & 73.50 & 24.42 \\
\hline Wheat hay & 17.14 & - & - & - \\
\hline Wheat straw & 13.30 & 4.16 & - & - \\
\hline Corn grain, high-moisture & - & 12.00 & - & - \\
\hline Corn grain, ground, dry & 4.26 & 8.00 & 11.78 & 27.12 \\
\hline Soybean meal & 10.40 & 16.29 & - & - \\
\hline Commercial concentrate ${ }^{1}$ & - & - & 14.71 & 22.04 \\
\hline Molasses, cane sugar & 3.69 & 5.20 & - & - \\
\hline Hydrogenated fatty acids & - & 1.83 & - & - \\
\hline Minerals and vitamins & 0.98 & 1.13 & - & 1.42 \\
\hline \multicolumn{5}{|l|}{ Nutrient composition } \\
\hline $\mathrm{CP}$ & 14.35 & 15.99 & 11.16 & 15.05 \\
\hline Starch & 4.49 & 23.46 & 11.12 & 23.09 \\
\hline Ether extract & 1.65 & 3.94 & 2.22 & 2.80 \\
\hline Forage & 81.65 & 42.05 & 75.02 & 52.23 \\
\hline $\mathrm{NDF}$ & 52.96 & 34.67 & 49.08 & 36.87 \\
\hline Forage NDF & 50.92 & 28.93 & 44.11 & 28.33 \\
\hline $\mathrm{ADF}$ & 30.35 & 19.73 & 25.40 & 21.94 \\
\hline ADL & 5.75 & 3.40 & 3.74 & 4.29 \\
\hline $\mathrm{NE}_{\mathrm{L}},{ }^{2} \mathrm{Mcal} / \mathrm{kg}$ of DM & 1.38 & 1.80 & 1.46 & 1.63 \\
\hline
\end{tabular}

${ }^{1}$ Contained flour extraction of toasted soybean, flour extraction of sunflower, dried stillage corn, wheat bran, alfalfa flour, wheat middlings, calcium carbonate, carob flour, fatty acid salts of palm oil, sodium chloride, molasses, dicalcium phosphate, sodium bicarbonate.

${ }^{2}$ According to NRC (2001) and calculated using Razio-Best software of Università Cattolica del Sacro Cuore (Piacenza, Italy). 
total globulin fraction was determined by subtracting albumin from total protein. Haptoglobin and ceruloplasmin concentrations were measured using methods proposed by Bertoni et al. (2008) adapted to ILAB 650 conditions. Plasma paraoxonase (PON, EC 3.1.8.1) activity was assessed by adapting the method of Ferré et al. (2002) to the ILAB 650. Oxidative stress was evaluated by measuring total reactive oxygen metabolites (ROM) as described by Bionaz et al. (2007); myeloperoxidase (MPO, EC 1.11.2.2) as described by Bionaz et al. (2007), via colorimetry based on the reaction of MPO contained in the plasma sample with hydrogen peroxide, which forms $\mathrm{H}_{2} \mathrm{O}$ and $\mathrm{O}^{-}$; o-dianisidine dihydrochloride, an electron donor, reacts with $\mathrm{O}^{-}$, releasing $\mathrm{H}_{2} \mathrm{O}$ and a colored compound. Ferric-reducing antioxidant power (FRAP) was measured using the colorimetric method of Benzie and Strain (1996); and advanced oxidation protein products (AOPP) as described by Hanasand et al. (2012). Plasma thiol groups (SHp) were determined by titration with 5,5-dithiobis-2-nitrobenzoic acid using a commercial kit (Diacron, Italy). Plasma retinol, tocopherol, and $\beta$-carotene were extracted with hexane and analyzed by reversed-phase HPLC using Spherisorb ODS-2, $3 \mu \mathrm{m}$, in a $150 \times 4.6 \mathrm{~mm}$ column (Alltech, Deerfield, IL); a UV detector set at $325 \mathrm{~nm}$ (for retinol), $290 \mathrm{~nm}$ (for tocopherol), or $460 \mathrm{~nm}$ (for $\beta$-carotene) and 80:20 methanol:tetrahydrofuran as the mobile phase. Bovine IL-1 $\beta$ (cat. no. ESS0027; Thermo Scientific, Rockford, IL) and IL-6 (cat. no. ESS0029; Thermo Scientific) plasma concentrations were determined using commercial kits.

\section{Milk Yield, Sample Collection, and Analysis}

Milk production was recorded at 7, 15, 21, 30, and $42 \mathrm{~d}$ in lactation from consecutive morning and evening milkings at each time point. On d 30, milk samples were collected in the morning and evening and analyzed separately for protein, fat, lactose, casein, and urea by mid-infrared procedures using the Milkoscan FT+ and FT120, respectively, for Simmental and Holstein milk samples (Foss Electric A/S, Hillerød, Denmark).

\section{Statistical Analysis}

Blood and milk yield data were subjected to ANOVA and analyzed using repeated measures in the MIXED procedure of SAS (version 9.4; SAS Institute Inc., Cary, $\mathrm{NC}$ ) according to the following model:

$$
\begin{aligned}
Y_{i j k l}=\mu & +B_{i}+G_{j}+T_{k}+B G_{i j}+G T_{j k} \\
& +B G T_{i j k}+c_{m: i j}+\varepsilon_{i j k l},
\end{aligned}
$$

where $Y_{i j k l}=$ dependent continuous variable, $\mu=$ overall mean, $B_{i}=$ fixed effect of breed $(i=$ Simmental vs. Holstein), $G_{j}=$ fixed effect of treatment (Trt; $j=$ PEG vs. CTR), $T_{k}=$ fixed effect of time (day; $-21,-7,1$, 3 , and 28), $B G_{i j}=$ interaction between breed and Trt; $G T_{j k}=$ interaction between Trt and time; $B G T_{i j k}=$ interaction between breed, Trt, and time; $c_{m: i j}=$ random effect of $m$ th animal (cow) nested within breed $\times$ Trt; and $\varepsilon_{i j k l}=$ residual error. The Kenward-Roger statement was used to compute the denominator degrees of freedom, whereas spatial power was used as the covariance structure. For milk components, the model in the MIXED procedure included only fixed effects of breed, treatment, and their interaction. Normality of data was checked by using the univariate procedure of SAS (ver. 9.4). Variables non-normally distributed were $\log _{10}$ transformed and once the output data were carried out from MIXED procedure, they were backtransformed. Data were considered significant at $P \leq$ 0.05 using PDIFF within the LSMEANS statement in SAS (ver. 9.3).

The prevalence of health problems recorded during the study was subjected to PROC FREQ of SAS, and $\chi^{2}$ analysis was used to assess whether prevalence differed among treatment groups within breed and overall between treatment groups. Significance was considered at $P \leq 0.05$ and tendencies at $P \leq 0.10$.

\section{RESULTS}

\section{Health Disorders}

Table 2 summarizes the incidence of health disorders occurring during the first month of lactation. Although the number of subjects selected for the trial was relatively low for both Simmental and Holstein cows, the incidences of mastitis, endometritis, ketosis, and displaced abomasum were similar between treatment groups in Simmental and Holstein cows $(P>0.05)$. However, the $\chi^{2}$ probability of association showed a tendency $(P=0.07)$ between Holstein PEG and CTR cows for the occurrence of retained placenta. In fact, Holstein PEG cows did not exhibit retained placenta, whereas 3 cows in the CTR group had retained placenta $(14.29 \%)$.

\section{Biomarkers of Energy and Muscle Body Mass}

Main effects of Trt, breed, day, and their interactions are reported in Table 3. Overall, pegbovigrastim injection did not affect glucose, FFA, BHB, creatinine, or urea $(P>0.1)$. As expected, glucose, creatinine, and urea decreased after calving (day, $P<0.01$ ). Overall, Simmental cows had higher levels of urea and creati- 
Table 2. Number (\%) of postcalving (d 1-30) health incidents in Simmental and Holstein dairy cows treated with pegbovigrastim (PEG) or with saline (CTR) at approximately $\mathrm{d}-7$ relative to calving and on the day of calving within $24 \mathrm{~h}$

\begin{tabular}{|c|c|c|c|c|c|c|c|c|c|}
\hline Item & \multicolumn{2}{|c|}{ Simmental $(26)^{1}$} & $\begin{array}{c}P \text {-value } \\
\chi^{2}\end{array}$ & \multicolumn{2}{|c|}{ Holstein (28) } & $\begin{array}{c}P \text {-value } \\
\chi^{2}\end{array}$ & \multicolumn{2}{|c|}{ Overall (54) } & $\begin{array}{c}P \text {-value } \\
\chi^{2}\end{array}$ \\
\hline Ketosis $^{3}$ & $2(14.29)$ & $1(8.33)$ & 0.63 & $5(35.71)$ & $4(28.57)$ & 0.68 & $7(25)$ & $5(19.23)$ & 0.23 \\
\hline Endometritis & - & $1(8.33)$ & 0.27 & $6(42.86)$ & $4(28.57)$ & 0.43 & $6(21.43)$ & $5(19.23)$ & 0.26 \\
\hline Displaced abomasum & - & - & - & $1(7.14)$ & - & 0.31 & $1(3.57)$ & - & 0.52 \\
\hline
\end{tabular}

${ }^{1}$ Values within parentheses represent the number of cows enrolled in the study by breed and treatment group.

${ }^{2}$ Defined as fetal membranes retained $\geq 24 \mathrm{~h}$ after calving.

${ }^{3}$ Defined as cows having BHB $>1.2 \mathrm{mmol} / \mathrm{L}$ in the first $2 \mathrm{wk}$ after calving.

nine, but lower levels of glucose and BHB compared with Holstein cows (breed, $P<0.05)$. Creatinine was affected by a Trt $\times$ breed $\times$ day interaction $(P<0.05$; Figure 1), mainly because of the overall higher values in Simmental cows throughout the time points evaluated $(P<0.05)$.

\section{Negative Acute Phase Proteins and Total Proteins}

Overall, treatment led to higher total protein and globulin compared with the control group $(P<0.05$; Table 4). For total protein, this was mainly related to higher values in Simmental PEG than in CTR cows and compared with both Holstein PEG and CTR cows (Trt $\times$ breed, $P<0.05$; Figure 2A). Holstein CTR had greater total protein at $-7 \mathrm{~d}$ than Simmental CTR $(P$ $<0.05$ ). Holstein PEG had also greater values at $28 \mathrm{~d}$ than Holstein CTR cows $(P<0.05)$, whereas at $1 \mathrm{~d}$, the Holstein PEG group had a lower concentration than the Simmental PEG group $(P<0.01)$. For Simmental cows, the PEG group started to have higher values at $-7 \mathrm{~d}$ and maintained this trend until $3 \mathrm{~d}$ compared with the CTR group $(P<0.05)$. Albumin was higher in Simmental PEG than in Holstein PEG or Simmental CTR groups at $1 \mathrm{~d}(P<0.05$; Figure $2 \mathrm{~B})$. The trend of albumin:globulin ratio in all groups was similar and did not differ statistically.

\section{Biomarkers of Liver Function}

Biomarkers of liver function are reported in Table 4, with the main effects of Trt, breed, day, and their interactions. As expected, time around parturition significantly affected all biomarkers reported herein (day, $P<0.01)$. Overall, GGT was higher in PEG than in CTR $(P<0.01)$; the PEG group had higher values throughout the postcalving period until $28 \mathrm{~d}$ compared with the CTR group (Trt $\times$ breed $\times$ day $P=0.04$; Figure 3A). Overall, the PEG group had higher ALP activity during the first $3 \mathrm{~d}$ after calving $(P<0.05$;
Figure 3B). The interaction Trt $\times$ breed $\times$ day $(P<$ 0.01) showed that Holstein PEG had higher ALP activity at $3 \mathrm{~d}$ compared with Holstein CTR and Simmental PEG groups $(P<0.01$; Figure $3 \mathrm{C})$, and higher ALP at $1 \mathrm{~d}$ compared with Simmental CTR group $(P<0.01)$. In the PEG group, there was a drastic increase in ALP at $1 \mathrm{~d}$ compared with $-7 \mathrm{~d}$, and then a significant decrease at 3 and $28 \mathrm{~d}$ in Simmental cows $(P<0.01)$. A different trend was observed for the Holstein PEG group, in which ALP gradually increased in the first $3 \mathrm{~d}$ and only drastically decreased at $28 \mathrm{~d}(P<0.01)$. Furthermore, we detected an overall effect of breed for cholesterol and PON $(P<0.05)$, such that Simmental cows had a higher cholesterol concentration but lower PON activity than Holstein cows.

\section{Positive Acute Phase Proteins and Cytokines}

Results of IL-6, IL-1 $\beta$, haptoglobin, and ceruloplasmin are reported in Table 5 . Time relative to parturition was significant in each model (day, $P<0.05$ ). There was an overall decrease in cytokines after parturition and higher values of ceruloplasmin and haptoglobin compared with precalving. A Trt $\times$ day effect was significant for IL-6 (Figure 4A) and IL-1 $\beta$ (Figure 4B), such that the PEG group had higher IL-6 at 3 and 28 $\mathrm{d}$ and higher IL-1 $\beta$ at $28 \mathrm{~d}$ after calving compared with the CTR group $(P<0.05)$. Overall, Holstein cows were characterized by a greater response in the production of these biomarkers (breed, $P<0.05$ ).

\section{Biomarkers of Oxidative Stress}

Overall, treatment with pegbovigrastim did not affect $(P>0.1)$ any biomarkers of oxidative stress reported in Table 6 (ROM, SHp, MPO, FRAP, AOPP); however, the Trt $\times$ breed $\times$ day interaction was significant for SHp $(P<0.05)$. Indeed, Simmental PEG showed a marked increase of SHp at $1 \mathrm{~d}$ compared with -7 d relative to parturition $(P<0.01)$, whereas Holstein 


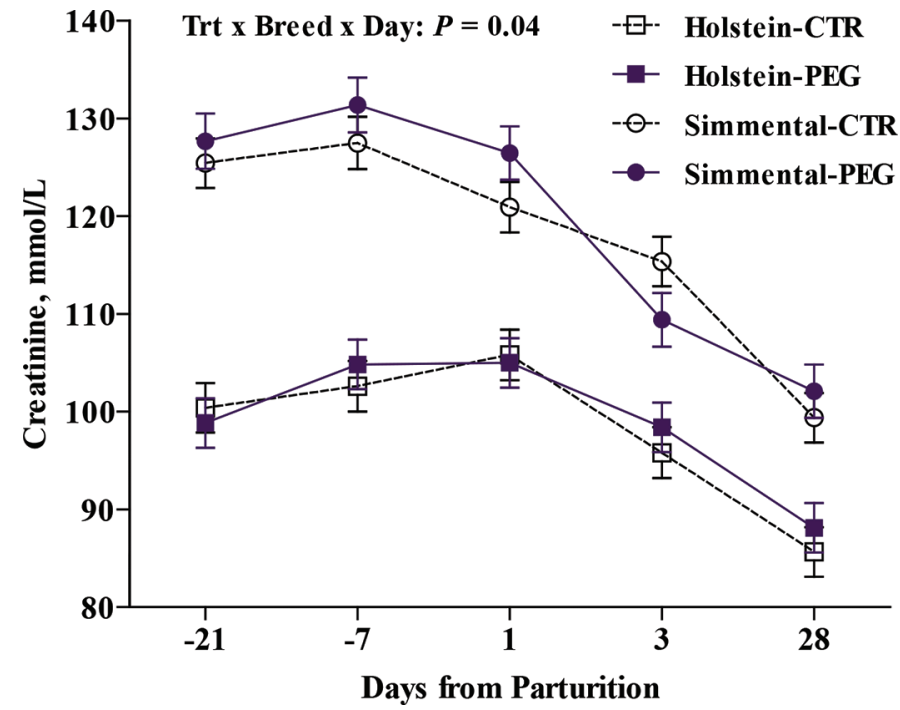

Figure 1. Plasma creatinine concentration (LSM \pm SEM) of Simmental and Holstein cows treated either with pegbovigrastim (PEG) or with saline (CTR) at approximately d -7 relative to calving and on the day of calving within $24 \mathrm{~h}$. Trt $=$ treatment.

PEG displayed similar values between -7 and $3 \mathrm{~d}$ relative to parturition (Figure 5). Regarding the day effect, overall ROM, SHp, MPO, and FRAP increased after parturition, whereas AOPP decreased in both Simmental and Holstein cows $(P<0.01)$. Overall, Holstein had higher values for ROM, SHp, MPO, and AOPP than Simmental cows $(P<0.01)$.

\section{Minerals and Vitamins}

Overall, $\mathrm{Ca}, \mathrm{P}, \mathrm{Mg}$, Zn, retinol, tocopherol, and $\beta$-carotene were not affected by pegbovigrastim $(P>$ 0.5 ; Table 7$)$. The interaction Trt $\times$ day was found to be significant only for $\mathrm{Zn}(P<0.01)$, with PEG cows having higher values at 1 and $3 \mathrm{~d}$ compared with CTR cows $(P<0.05$; Figure 6$)$. Overall, these biomarkers were affected by time relative to parturition, with the lowest values at $1 \mathrm{~d}$ after parturition and then gradually increasing $(P<0.01)$. Overall, Holstein cows had higher concentrations of $\mathrm{Mg}, \mathrm{Zn}$, tocopherol, and $\beta$-carotene, but lower $\mathrm{P}$ than Simmental cows $(P<$ $0.05)$.

\section{Milk Yield and Quality}

As expected, Holstein cows had greater milk production throughout early lactation (between 7 and $42 \mathrm{~d}$ after calving) than Simmental cows $(P<0.01$; Figure $7)$. The average milk production was $33.11 \pm 1.16$ and $26.70 \pm 1.21 \mathrm{~kg} / \mathrm{d}$ for Holstein and Simmental cows, respectively. No significant differences were detected 
LOPREIATO ET AL.

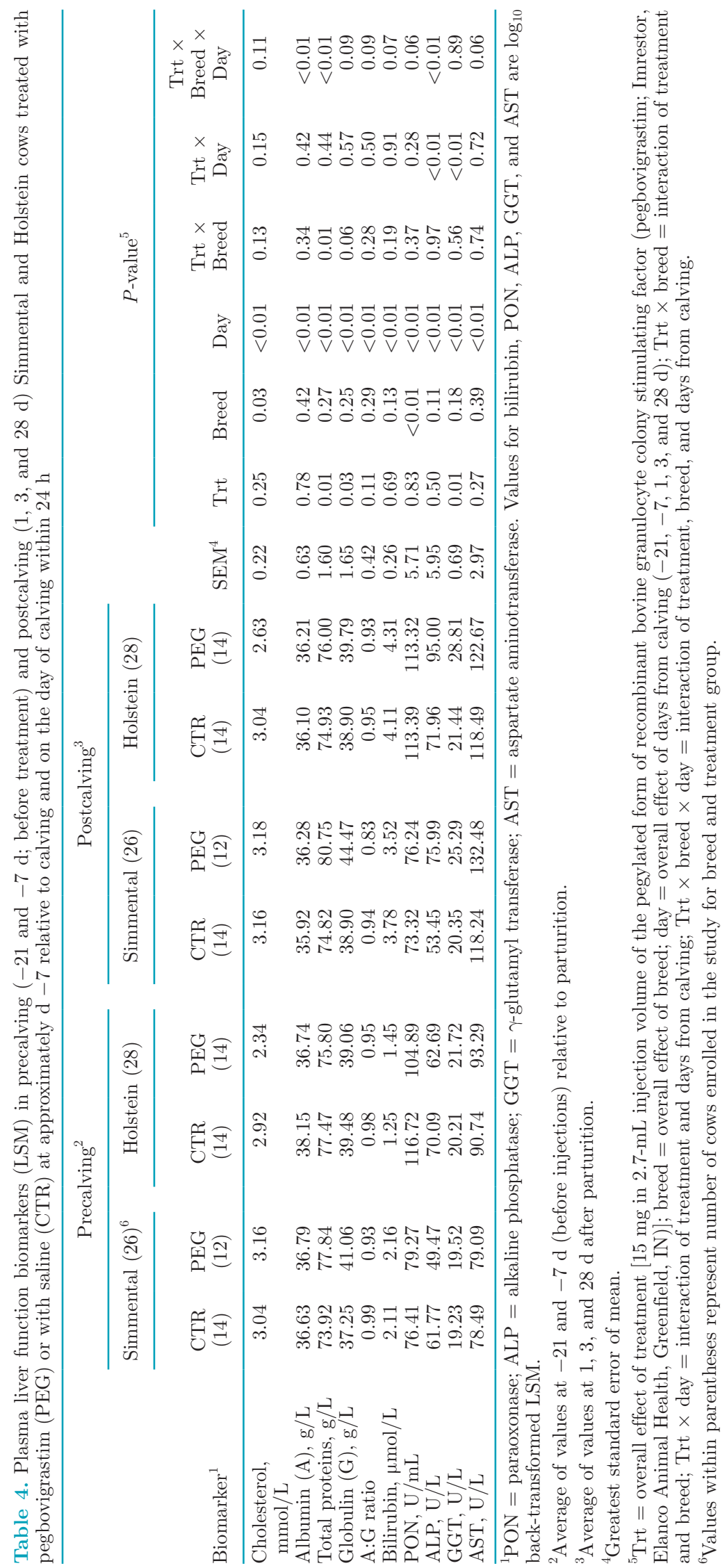


between PEG and CTR groups for both breeds. Overall, no differences were observed between PEG and CTR cows for milk quality traits (Figure 8). However, Holstein cows produced milk with higher levels of lactose (Figure 8) and lower levels of urea compared with Simmental cows at $30 \mathrm{~d}$ in lactation $(23.37 \pm 1.12$ vs. $28.46 \pm 1.15 \mathrm{mg} / \mathrm{dL} ; P<0.05)$.

\section{DISCUSSION}

Pegbovigrastim is a commercial, long-acting analog of bovine G-CSF used in periparturient dairy cows that promotes an increased count of circulating mature $\mathrm{PMN}$ in the blood and their relative immune function (Kimura et al., 2014; McDougall et al., 2017; Zinicola et al., 2018). However, a complete evaluation of pegbovigrastim effect on the inflammo-metabolic profile of
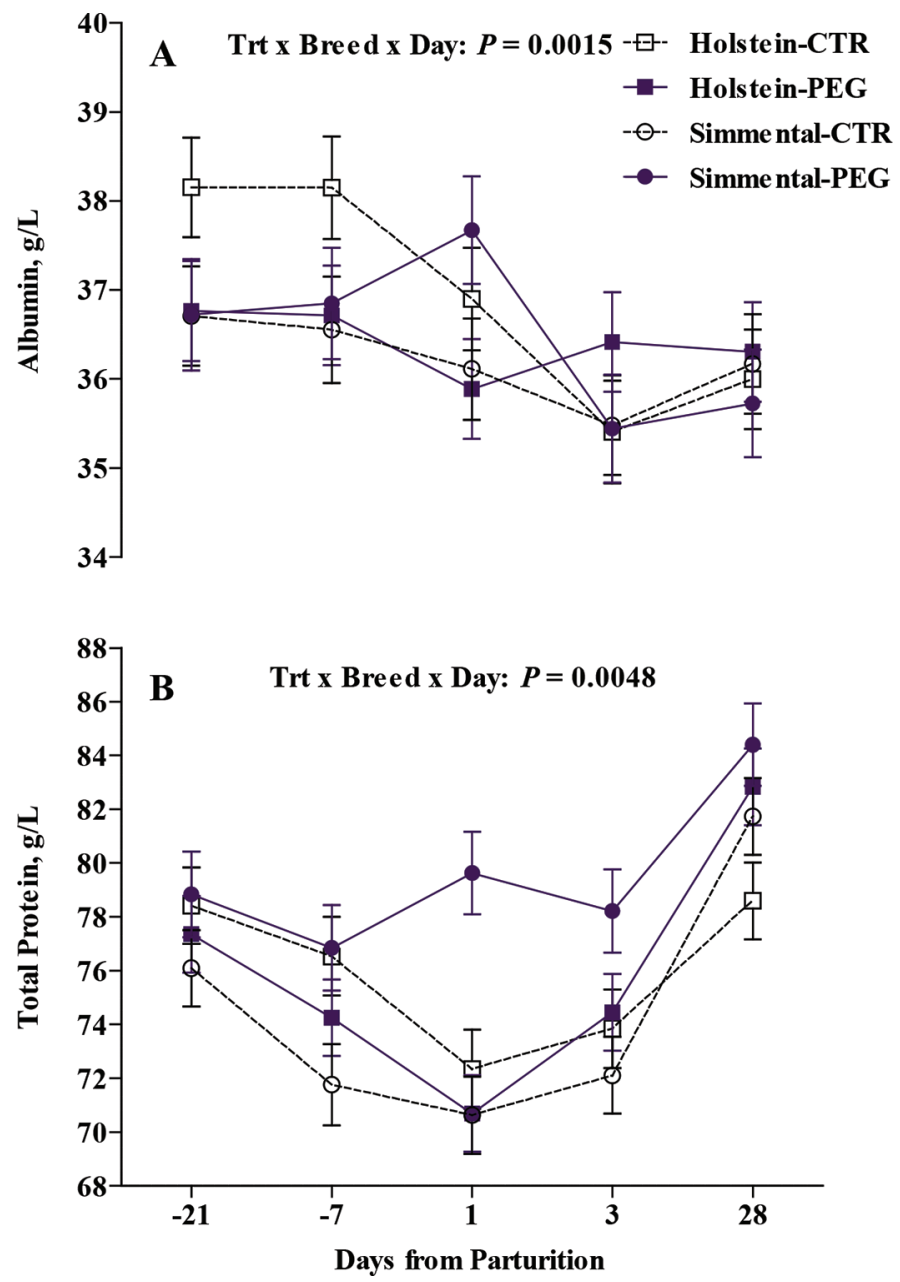

Figure 2. Plasma albumin (A) and total protein (B) concentrations (LSM \pm SEM) of Simmental and Holstein cows treated either with pegbovigrastim (PEG) or with saline (CTR) at approximately $\mathrm{d}$ -7 relative to calving and on the day of calving within $24 \mathrm{~h}$. Trt $=$ treatment.
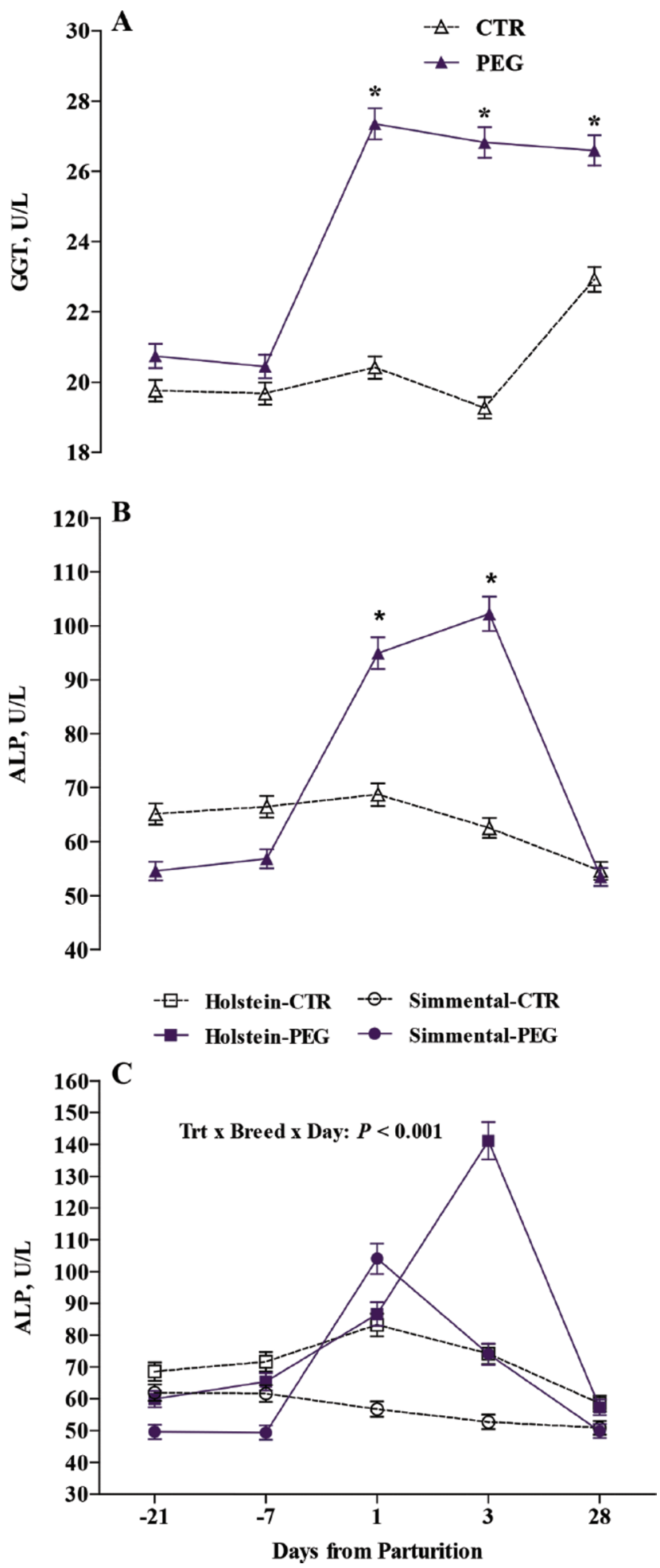

Figure 3. Least squares means \pm SEM concentrations of $\gamma$-glutamyl transferase (GGT; A) and alkaline phosphatase (ALP; B) for overall cows treated either with pegbovigrastim (PEG) or with saline (CTR). And, ALP (C) of Simmental and Holstein cows treated either with pegbovigrastim (PEG) or with saline (CTR) at approximately $\mathrm{d}-7$ relative to calving and on the day of calving within $24 \mathrm{~h}$. Asterisks indicate days where biomarkers differed between treatment (Trt) groups $(P<0.05)$. 
blood has not previously been reported. In addition to exploring a wide range of blood biomarkers to assess energy condition, inflammatory response, liver functionality, and oxidative status after pegbovigrastim treatment, we focused on treatment responses in different breeds during the transition period, enrolling Holstein cows, highly specialized for milk production, and Simmental cows, a dual-purpose breed selected for both meat and milk production. Considering that the Simmental and Holstein cows enrolled in the trial were from 2 different farms, the statistical comparison of metabolic status between breeds is not straightforward, even though the results obtained herein from injection of pegbovigrastim in the 2 breeds shed light on the response to the treatment first and then on the metabolic pattern changes in the period around parturition.

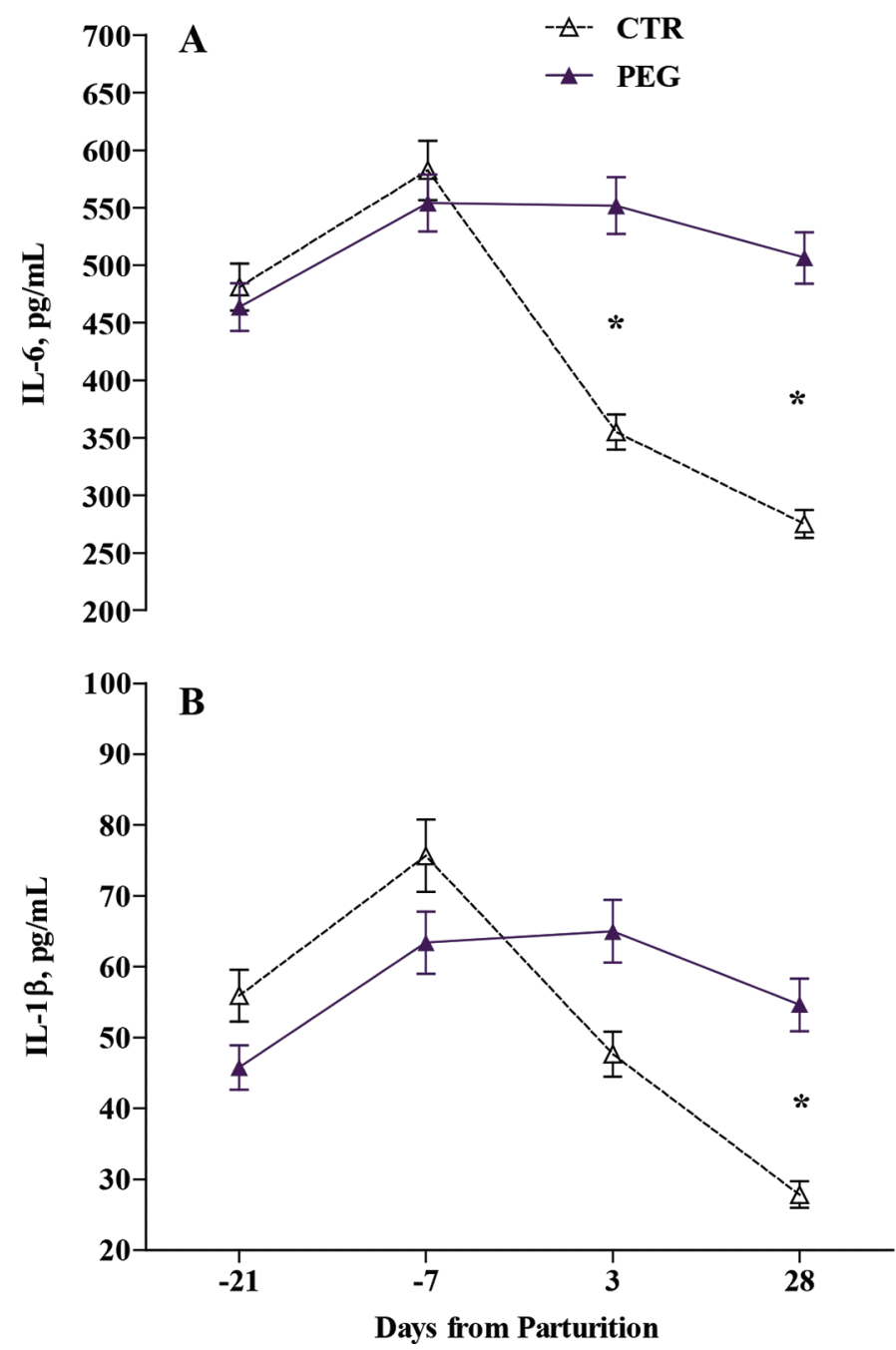

Figure 4. Least squares means \pm SEM concentrations of IL-6 (A) and IL-1 $\beta$ (B) for overall cows treated either with pegbovigrastim (PEG) or with saline (CTR) approximately d -7 relative to calving and on the day of calving within $24 \mathrm{~h}$. Asterisks indicate days where biomarkers differed between treatment groups.

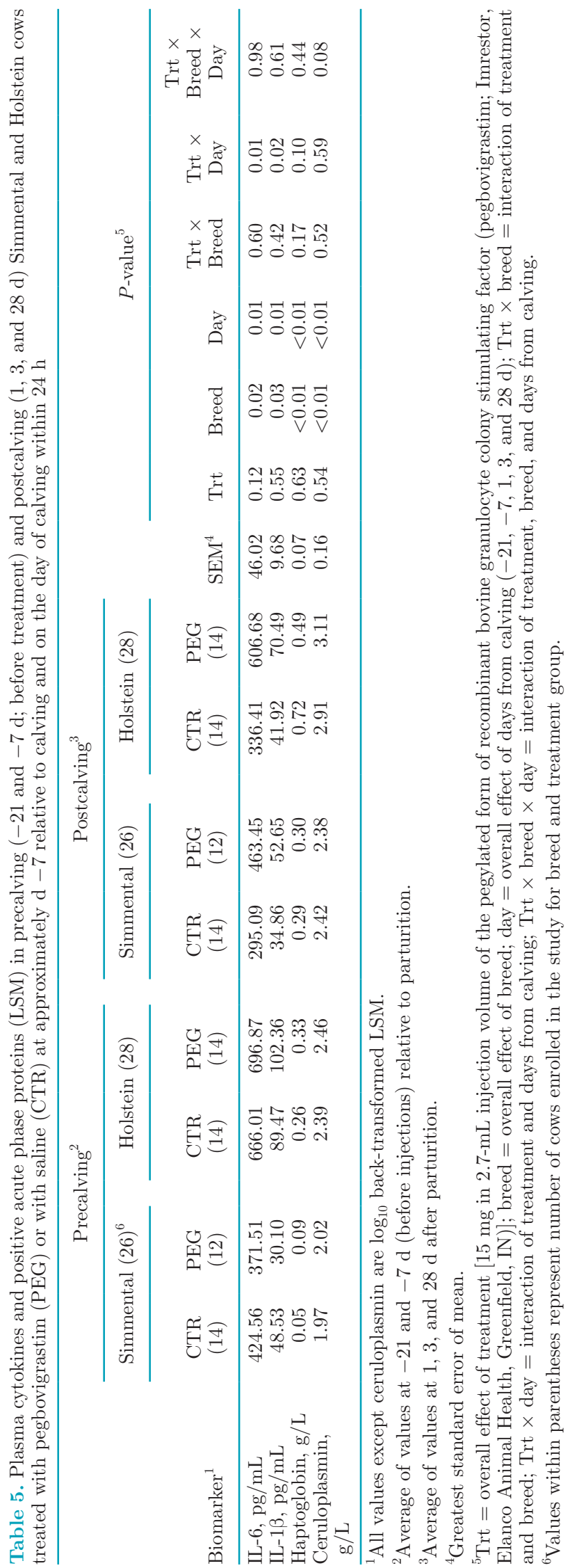




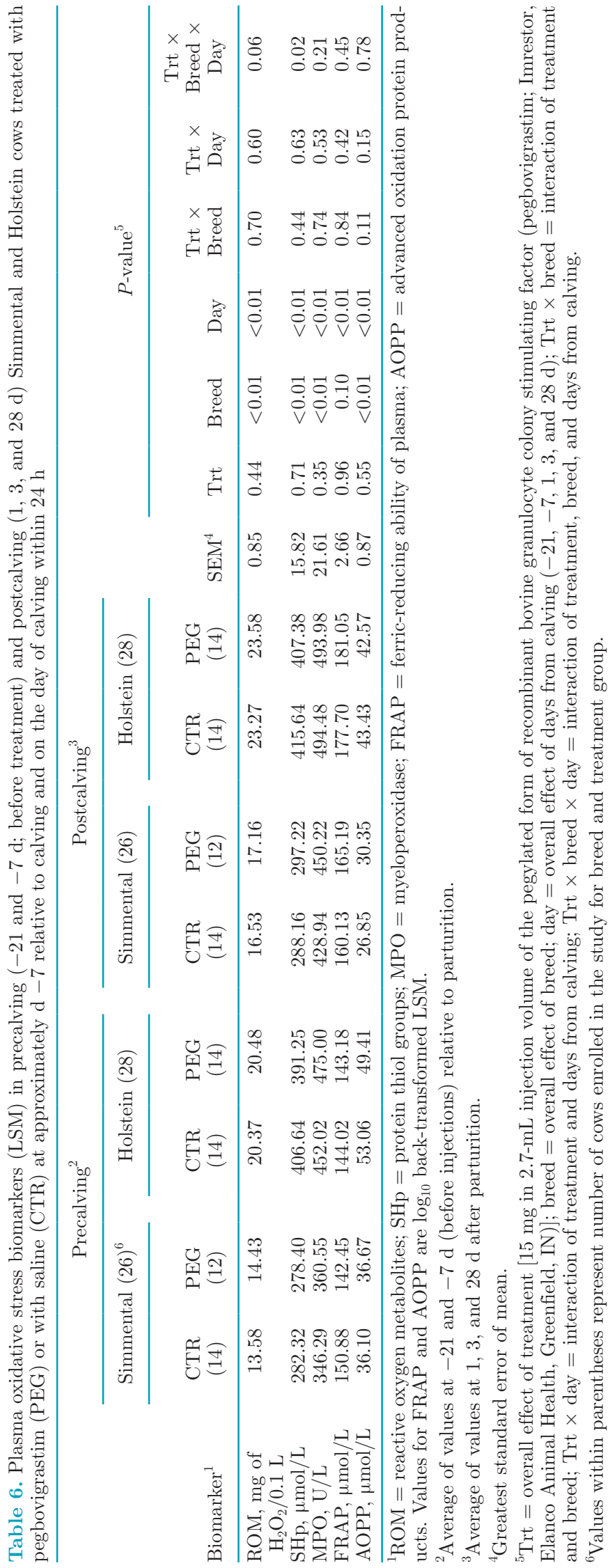

According to product usage guidelines for pegbovigrastim, the first dose should be injected at approximately $7 \mathrm{~d}$ before expecting calving and the second dose within $24 \mathrm{~h}$ after parturition. Thus, based on a predicted calving list generated by the trial site herdmanagement software, animals were observed regularly to identify those that exhibited clinical signs and would calve within approximately $7 \mathrm{~d}$. For cows allocated to the pegbovigrastim treatment, the first dose was administered approximately $7 \mathrm{~d}$ before expected parturition and the second within $24 \mathrm{~h}$ after calving. With this treatment protocol, our study was in complete agreement with previous studies, allowing a close comparison of results (Kimura et al., 2014; McDougall et al., 2017; Ruiz et al., 2017; Zinicola et al., 2018), and also reflected field conditions of pegbovigrastim application.

\section{Health Disorders}

Studies conducted for regulatory approval in New Zealand, the United States, and Europe have found that pegbovigrastim treatment reduces the incidence of clinical mastitis in early lactation of Holstein dairy cows. At least in Europe, the main commercial use of pegbovigrastim in a herd prophylactic management program is to reduce the risk of clinical mastitis in periparturient dairy cows and heifers during the 30 $\mathrm{d}$ following calving. In this context, previous studies reported the efficacy of pegbovigrastim to reduce the

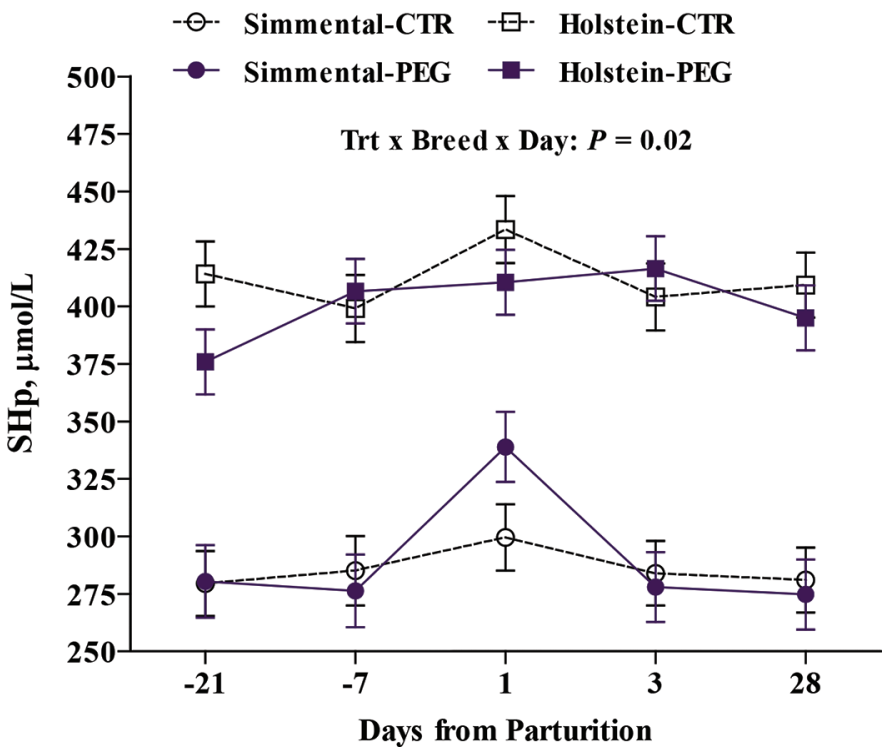

Figure 5. Least squares means \pm SEM concentration of plasma thiol groups (SHp) in Simmental and Holstein cows treated either with pegbovigrastim (PEG) or with saline (CTR) at approximately $\mathrm{d}-7$ relative to calving and on the day of calving within $24 \mathrm{~h}$. Trt $=$ treatment. 


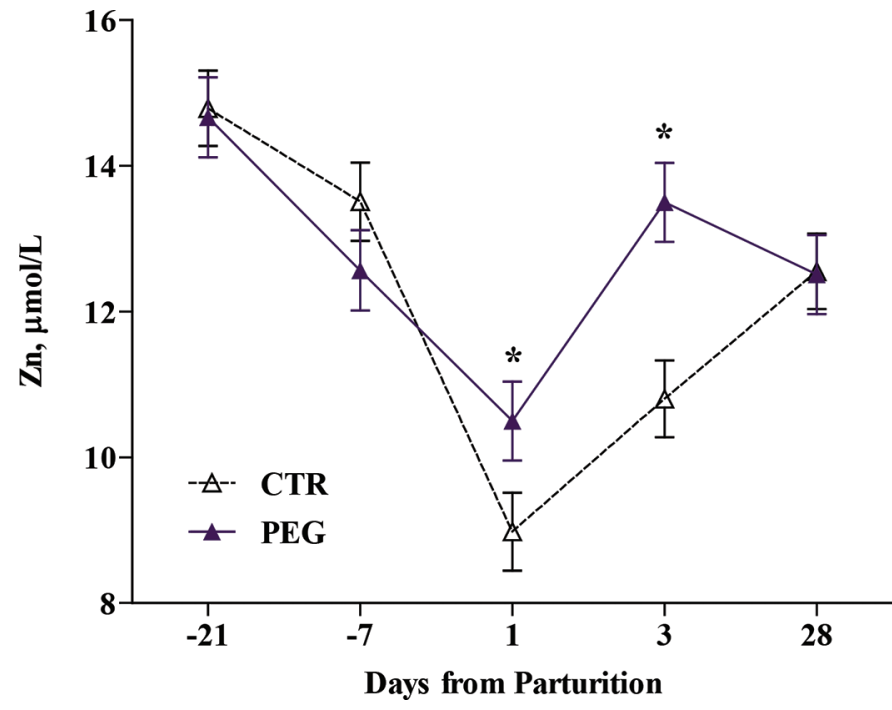

Figure 6. Plasma zinc concentration (LSM \pm SEM) for overall cows treated either with pegbovigrastim (PEG) or with saline (CTR) approximately $\mathrm{d}-7$ relative to calving and on the day of calving within $24 \mathrm{~h}$. Asterisks indicate days where biomarkers differed between treatment groups $(P<0.05)$.

incidence of mastitis (Hassfurther et al., 2015; Canning et al., 2017; Ruiz et al., 2017). However, in the current study, the incidence of mastitis did not differ between the PEG and CTR groups of each breed. Although

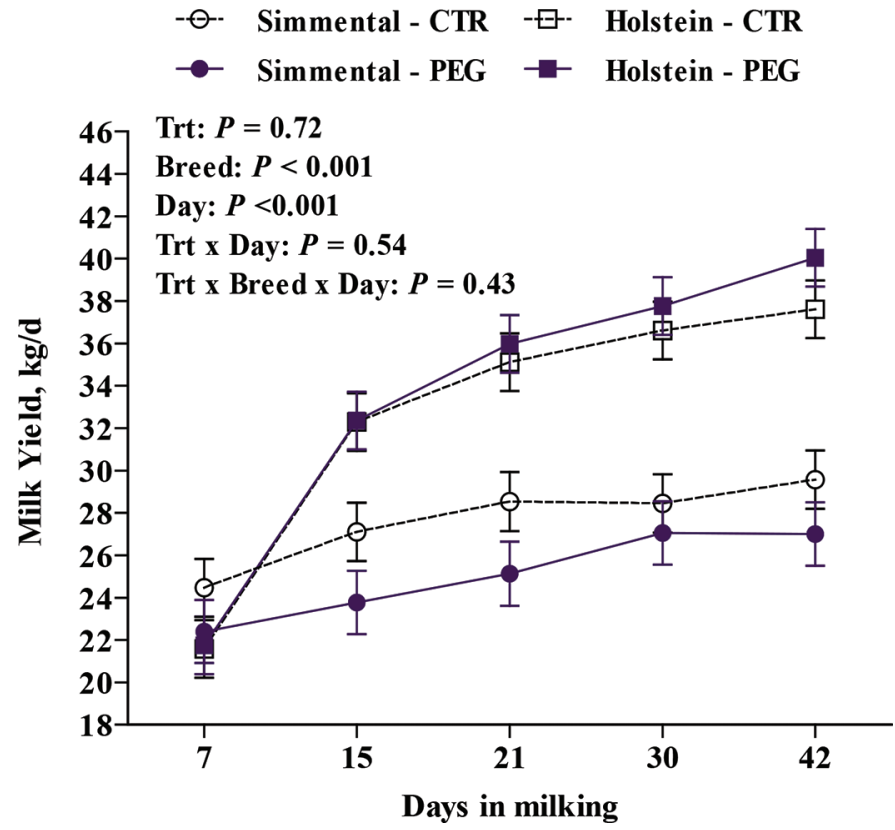

Figure 7. Milk yield (LSM \pm SEM) of Simmental and Holstein cows recorded through the first month of lactation. Cows were treated either with pegbovigrastim (PEG) or with saline (CTR) at approximately $\mathrm{d}-7$ relative to calving and on the day of calving within $24 \mathrm{~h}$. Trt $=$ treatment.

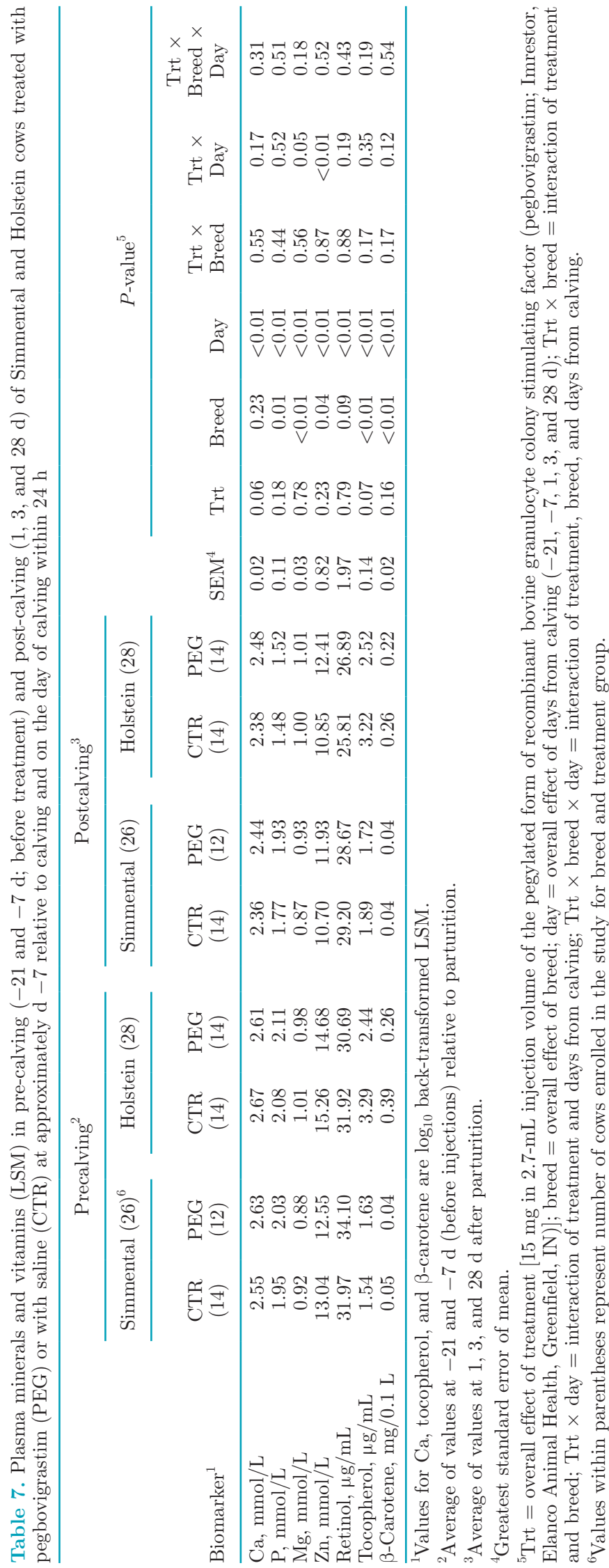


our study had insufficient power to demonstrate clinical health benefits in response to pegbovigrastim, it is important to note that the magnitude of reduction in mastitis incidence varies substantially between farms in previous studies (Ruiz et al., 2017; Zinicola et al., 2018). Indeed, according to Zinicola et al. (2018), the lack of effect of pegbovigrastim to increase neutrophil phagocytic activity, oxidative burst, and MPO function (Kimura et al., 2014; McDougall et al., 2017) supports the finding of controversial results among different studies.

To our knowledge, no published data are available on neutrophil functions in milk that could clarify this aspect. Interestingly, in the current study, Holstein PEG cows tended to have lower probability for the occurrence of retained placenta compared with Holstein CTR, with no Holstein PEG cows having this condition. These findings are in agreement with Ruiz et al. (2017), who found an overall $4.15 \%$ reduction in the incidence of retained placenta with pegbovigrastim treatment compared with control animals. This result is supported by the relationship between retained placenta and leukocyte function (Kimura et al., 2002). In fact, cows developing retained placenta have impaired neutrophil function that can be observed before calving, suggesting that decreased neutrophil function is not the result of retained placenta but is likely the cause. Hence, increasing the available pool of leukocytes in circulation using pegbovigrastim before calving could increase the flux toward the uterine tract.

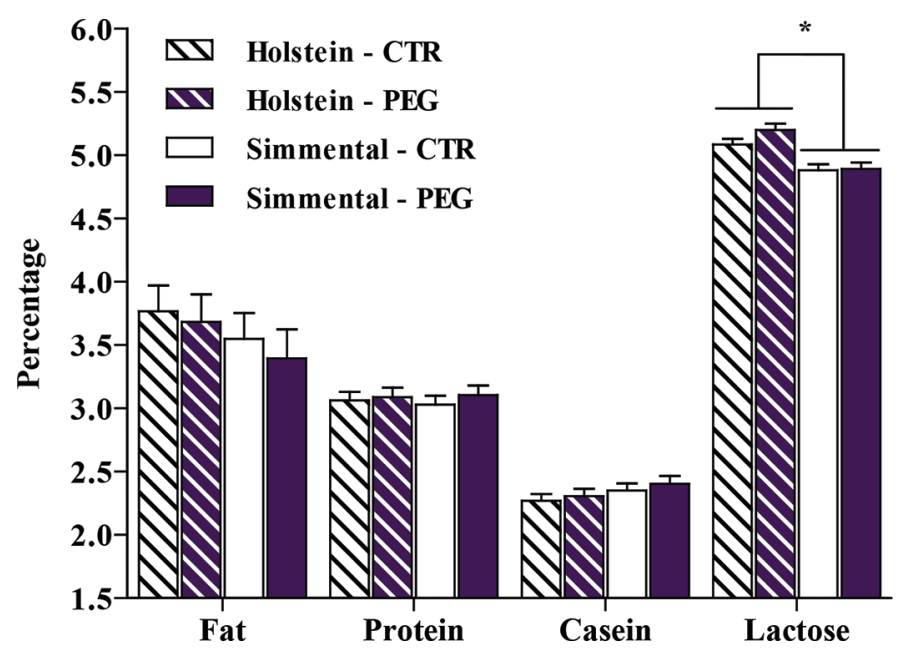

Figure 8. Milk quality assessed by evaluation of fat, protein, casein, and lactose (LSM \pm SEM) of Simmental and Holstein cows at $30 \mathrm{~d}$ after parturition. Cows were treated either with pegbovigrastim (PEG) or with saline $(\mathrm{CTR})$ at approximately $\mathrm{d}-7$ relative to calving and on the day of calving within $24 \mathrm{~h}$. * Lactose differed between Holstein and Simmental $(P<0.05)$.

\section{Energy and Nitrogen Metabolism}

The onset of lactation inevitably leads to a greater demand of glucose, which is estimated to increase 2.5 times from the prepartum requirement (Reynolds et al., 2003; Aschenbach et al., 2010), and higher demands in general for energy substrates, such as fat and protein, for milk production immediately after parturition. This is in agreement with the gradual decrease in glucose after calving and concomitant increase in FFA (mobilized from adipose tissue to cover energy demand), that in turn leads to increased BHB (Drackley, 1999) from incomplete oxidation of FFA. Overall, in this study, pegbovigrastim injections had no effects on energy and protein metabolism. However, the breed effect highlighted some differences between Simmental and Holstein cows. Holstein cows showed higher levels of glucose and BHB, and Simmental cows had lower levels of creatinine and urea. Higher blood glucose concentration in Holstein cows mainly during the postcalving period could be a result of higher $\mathrm{NE}_{\mathrm{L}}$ and intake (according to the diet formulation) compared with Simmental cows (Table 1). Indeed, glucose production is highly correlated with digestible energy intake (Bell and Bauman, 1997), and conversion of propionate to glucose by the liver is more closely linked to $\mathrm{NE}_{\mathrm{L}}$ intake after calving (Drackley et al., 2001).

The lower values of BHB in Simmental cows agree with Urdl et al. (2015) in both the pre- and postcalving phases compared with Holsteins. Furthermore, Curone et al. (2018) observed in Rendena cows (a rustic dual-purpose animal) that BHB level was lower overall, mainly after calving (10 d), compared with that in Holstein cows. These findings clearly demonstrate lesser mobilization of body reserves and better oxidation of the fatty acids in the liver of cows belonging to breeds that did not undergo selective pressure for increased milk production. In general, the effect of breed in the current study could be based on differences in EB caused primarily by differing energy intake or milk energy and quantity output, which could represent a homeorhetic regulation (Urdl et al., 2015).

In contrast, the protein metabolism of Simmental cows was demonstrated by higher levels of creatinine and urea compared with Holstein. Milk urea concentration was also higher in Simmental cows than in Holsteins. The higher urea production in Simmental could be supported by mobilization of muscle protein confirmed by the lower CP intake and higher levels of creatinine throughout the entire period. In fact, creatinine is an important indicator of body muscle mass, and its concentration typically starts to decrease around parturition and beyond (Pires et al., 2013). Pires et al. (2013) observed that cows with low BCS 
had lower creatinine concentration compared with cows with medium and high BCS. Simmental cows are characterized by a higher BCS and, because this breed remains dual-purpose (albeit to a lesser degree than before), Simmental cows are characterized by greater body muscle mass than Holstein cows.

\section{Plasma Negative Acute Phase Protein and Total Proteins}

Pegbovigrastim increased total proteins and globulins, with higher values of total protein observed in Simmental cows, especially in the first $3 \mathrm{~d}$ after parturition compared with Simmental CTR and Holstein CTR or PEG. This pattern was confirmed in the higher albumin levels at $1 \mathrm{~d}$ after calving in Simmental PEG compared with Simmental CTR. Nevertheless, these values remain within the reference interval established for the periparturient period (Moretti et al., 2017), suggesting that PEG treatment did not affect plasma proteins levels. The marked increase of albumin observed in Simmental PEG, although within the reference interval, indicates a certain degree of dehydration (Russell and Roussel, 2007), which causes hemoconcentration. However, the effect of pegbovigrastim on total proteins and albumin immediately after parturition for Simmental cows warrants further investigation, because no differences were obtained for albumin-to-globulin ratio between treated and control cows. However, the need remains to address the use of pegbovigrastim in studies that account for the dosage in different breeds, evaluating the duration of activity.

\section{Liver Functionality}

During the transition period and mainly after parturition, the liver is essential for metabolism of FFA released from adipose depots (Drackley, 1999). In this respect, cows with optimal liver function are able to face periparturient challenges more efficiently, with reduced signs of metabolic stress and inflammation (Bionaz et al., 2007; Bertoni and Trevisi, 2013). Biomarkers of liver function are represented by enzymes released in the blood and previously tested to evaluate liver efficiency (Ferré et al., 2002; Bionaz et al., 2007; Bertoni et al., 2008). Although GGT is present in many tissues, it is considered specific for liver and is probably a better indicator of hepatic disease than ALP in ruminants; it is also an important indicator of hepatobiliary disorders and cholestasis in ruminants (Russell and Roussel, 2007). To our knowledge, this study is the first to report a side effect of treatment with pegbovigrastim for GGT and ALP, leading to higher activity of these 2 enzymes. However, the values reported herein fall within the normal range (Moretti et al., 2017). Alkaline phosphatase in serum has been shown to consist of isoenzymes originating from liver and bone, which have a long half-life, and these isoenzymes are mainly utilized as indices of liver function or bone metabolism in cattle (Smith, 2014). Although the levels of GGT and ALP were high in PEG cows, the concentrations of both enzymes in blood are known to increase after calving (Bertoni et al., 2008). Overall, the concentrations of GGT and ALP postpartum were within the typical range expected for early postpartal cows without clinical disease (Cozzi et al., 2011; Bertoni and Trevisi, 2013; Moretti et al., 2017).

Besides the fact that values were within previously reported reference ranges, the increased values of GGT in PEG cows could be explained by metabolism of polyethylene glycol used to conjugate rbG-CSF. Pegylation has become an increasingly common method of improving the half-life of biological products (Yang et al., 2004), mainly by reducing urinary excretion of the molecule but also by reducing enzyme degradation (Veronese and Pasut, 2005). Moreover, it has been shown that ALP production in neutrophils is induced by G-CSF (Sato et al., 1991); thus, the drastic increase in ALP activity in both Simmental and Holstein PEG cows, especially at 1 and $3 \mathrm{~d}$ after calving, could be due to this mechanism.

Among biomarkers investigated for liver function, Simmental cows showed greater plasma cholesterol but lesser PON activity than Holstein cows. These results are inconsistent with previous results from our group (Bionaz et al., 2007; Bertoni and Trevisi, 2013). Activity of PON is strongly associated with cholesterol, given that high-density lipoprotein (HDL) cholesterol represents a carrier for PON, and also plays a pivotal role in its availability in the circulation (Bionaz et al., 2007). Thus, these differences between Simmental and Holstein may be explained as a physiological characteristic because the breeds' purposes differ. One interpretation could relate to compositional factors of HDL in the 2 breeds affecting the binding of PON to the surface of HDL and consequently a different shift between PON in plasma and surface PON-HDL (Trevisi et al., 2012b).

\section{Inflammation and Cytokines}

The inflammatory process is a well-conserved mechanism to overcome adverse stimuli and restore homeostasis. Dairy cows experience some degree of inflammation after parturition (Bertoni et al., 2004; Sordillo, 2016). In classifying the degree of inflammation based on plasma concentration of acute-phase protein, Bertoni et al. (2008) reported that higher inflammation levels 
were associated with the risk of transition disorders and impaired animal performance during early lactation. Ceruloplasmin and haptoglobin represent the major positive acute phase proteins produced by the liver and are useful biomarkers to evaluate chronic inflammation (Bertoni and Trevisi, 2013). Pegbovigrastim treatment (and its interaction with time) did not affect these 2 proteins, even though IL- 6 and IL- $1 \beta$ were higher overall in the postpartum period of PEG group compared with CTR. The role of IL-6 is to activate target genes involved in differentiation, survival, apoptosis, and proliferation; thus, it has pro- as well as anti-inflammatory properties and is one of the major players in hematopoiesis (Heinrich et al., 2003). In contrast, the functions of IL-1 $\beta$ result in a proinflammatory status, and it has a pivotal role in acute and chronic inflammation and exerting pleiotropic effects on a variety of cells. Considering only CTR animals, cytokines decreased dramatically soon after parturition relative to the dry period. Given the specific roles of IL- 6 and IL-1 $\beta$, the chronological trend in the cytokine response is in line with the well-established immunosuppression during the transition period into lactation (Kehrli et al., 1989; Trevisi et al., 2015). As a result of stimulating the innate immune system by pegbovigrastim injection, cytokine levels did not decrease during the postpartum period in the PEG group.

In human studies, G-CSF induces a switch in the responsiveness of blood leukocytes, characterized by a release of proinflammatory cytokines (Hartung et al., 1995). However, values of IL- 6 and IL- $1 \beta$ in the PEG group in the current study after calving would not suggest an enhanced inflammatory status, confirmed by acute positive phase proteins. On the contrary, we speculate that the greater plasma concentrations of these cytokines reflect a greater number and functionality of immune cells, given that IL- 6 and IL-1 $\beta$ are checkpoint regulators of neutrophil recruitment, trafficking, and maturation during an inflammatory response. Future efforts should focus on the role these cytokines play in the complex pattern of inflammation and whether a greater response after parturition represents an exerting or relieving of inflammatory status.

\section{Oxidative Pattern, Vitamins, and Minerals}

Overall, among the biomarkers studied to evaluate oxidative stress, pegbovigrastim did not improve or impair any of them. Simmental PEG cows had a higher SHp concentration at $1 \mathrm{~d}$ after calving compared with CTR cows. The SHp are considered a significant component of the extra-cellular antioxidant defense system against oxidative stress (Frei et al., 1988; Ueland et al., 1996). Under physiological conditions, SHp are the most chemically reactive sites and have strong reducing properties. Total SHp of plasma represent the sulfhydryl groups of albumin, L-cysteine, and homocysteine (Soriani et al., 1994; Moran et al., 2001). Hence, higher values at $1 \mathrm{~d}$ postpartum reflect the higher values of albumin reported for Simmental PEG cows. The current study also shed light on the differences between Simmental and Holstein cows regarding the entire repertoire of biomarkers involved in the oxidative pattern. In fact, Holstein cows were characterized by higher values for pro-oxidant molecules (ROM and MPO), anti-oxidant molecules (FRAP and SHp), and terminal products of proteins exposed to free radicals (AOPP), indicating that Holsteins might experience greater oxidative stress but also have a better activated system to counteract it (mainly after parturition) compared with Simmental cows.

Overall, cows treated with pegbovigrastim were characterized by higher levels of Zn at 1 and $3 \mathrm{~d}$ after calving compared with CTR cows. To understand the specific role of $\mathrm{Zn}$ during inflammatory processes, it is noteworthy to report a study from Erskine and Bartlett (1993) reported a drastic decrease in serum Zn after Escherichia coli-induced mastitis. This suggests a natural response during inflammation or that the onset of a disease increased the sequestration of $\mathrm{Zn}$ by binding proteins such as lactoferrin, resulting in decreased $\mathrm{Zn}$ availability for bacterial growth (Erskine and Bartlett, 1993; Underwood and Suttle, 1999). Furthermore, addition of $\mathrm{Zn}$ to milk enhances growth of $E$. coli in vitro (Lohuis et al., 1988), which supports an antibacterial role of $\mathrm{Zn}$ sequestration. Thus, we speculate that the higher levels of $\mathrm{Zn}$ in PEG cows resulted from increased synthesis of Zn-binding proteins involved in antimicrobial activity (i.e., lactoferrin). In our last analysis of this study, we found no differences between groups for $\beta$-carotene, tocopherol, or retinol. Rather, Holstein cows showed higher values of these vitamins that could be explained by differences in forages used in the diet compared with those for Simmental cows. Holstein cows were fed a corn silage-based TMR diet, whereas Simmental cows were fed a hay-based TMR. However, the decrease in vitamin levels after calving, especially in the first week, is in agreement with previous studies (Trevisi et al., 2013; Osorio et al., 2014; Batistel et al., 2018).

\section{CONCLUSIONS}

The response observed in metabolic plasma biomarkers after pegbovigrastim treatment in Simmentals and Holsteins did not differ from the response of cows not treated. However, our data shed light on the different metabolic adaptations that occur during the transition 
period in Simmental and Holstein cows, in terms of different energy, inflammatory, and oxidative pattern responses. Treatment with pegbovigrastim to stimulate the immune system led to inconsistent increases in $\gamma$-glutamyl transferase and alkaline phosphatase. In light of data obtained for plasma cytokines, we report for the first time an effect of pegbovigrastim to maintain stable cytokine levels through the first month after parturition, in contrast to control cows, which experienced a drastic decrease immediately after calving and beyond. These results support an immunomodulatory action of pegbovigrastim around parturition, when dairy cows are highly immunosuppressed. Finally, milk production was not improved, but also not impaired, by pegbovigrastim, indicating a lack of detrimental effect that could be expected with the elevated levels of cytokines observed.

\section{ACKNOWLEDGMENTS}

This project was financially supported by the Interdepartmental Services Centre of Veterinary for Human and Animal Health (Magna Graecia University, Catanzaro, Italy), by the Department of Animal Sciences, Food and Nutrition (DIANA), Faculty of Agriculture, Food and Environmental Science (Università Cattolica del Sacro Cuore, Piacenza, Italy), and by the "Romeo ed Enrica Invernizzi foundation" (Milan, Italy). A special thanks to Annarita Ferrari and Giorgia Lovotti (DIANA, Università Cattolica del Sacro Cuore, Piacenza, Italy) for the technical assistance in the blood assessment.

\section{REFERENCES}

Aschenbach, J. R., N. B. Kristensen, S. S. Donkin, H. M. Hammon, and G. B. Penner. 2010. Gluconeogenesis in dairy cows: The secret of making sweet milk from sour dough. IUBMB Life 62:869-877. https://doi.org/10.1002/iub.400.

Batistel, F., J. M. Arroyo, C. I. M. Garces, E. Trevisi, C. Parys, M. A. Ballou, F. C. Cardoso, and J. J. Loor. 2018. Ethyl-cellulose rumen-protected methionine alleviates inflammation and oxidative stress and improves neutrophil function during the periparturient period and early lactation in Holstein dairy cows. J. Dairy Sci. 101:480-490. https://doi.org/10.3168/jds.2017-13185.

Bell, A. W. W., and D. E. E. Bauman. 1997. Adaptations of glucose metabolism during pregnancy and lactation. J. Mammary Gland Biol. Neoplasia 2:265-278. https://doi.org/10.1023/A: 1026336505343.

Benzie, I. F. F., and J. J. Strain. 1996. The ferric reducing ability of plasma (FRAP) as a measure of "antioxidant power": The FRAP assay. Anal. Biochem. 239:70-76. https://doi.org/10.1006/abio .1996 .0292 .

Bertoni, G., and E. Trevisi. 2013. Use of the liver activity index and other metabolic variables in the assessment of metabolic health in dairy herds. Vet. Clin. North Am. Food Anim. Pract. 29:413-431. https://doi.org/10.1016/j.cvfa.2013.04.004.

Bertoni, G., E. Trevisi, X. Han, and M. Bionaz. 2008. Effects of inflammatory conditions on liver activity in puerperium period and consequences for performance in dairy cows. J. Dairy Sci. 91:33003310. https://doi.org/10.3168/jds.2008-0995.

Bertoni, G., E. Trevisi, and F. Piccioli-Cappelli. 2004. Effects of acetyl-salicylate used in post-calving of dairy cows. Vet. Res. Commun. 28:217-219. https://doi.org/10.1023/B:VERC.0000045410 .86004 .03 .

Bionaz, M., E. Trevisi, L. Calamari, F. Librandi, A. Ferrari, and G. Bertoni. 2007. Plasma paraoxonase, health, inflammatory conditions, and liver function in transition dairy cows. J. Dairy Sci. 90:1740-1750. https://doi.org/10.3168/jds.2006-445.

Canning, P., R. Hassfurther, T. TerHune, K. Rogers, S. Abbott, and D. Kolb. 2017. Efficacy and clinical safety of pegbovigrastim for preventing naturally occurring clinical mastitis in periparturient primiparous and multiparous cows on US commercial dairies. J. Dairy Sci. 100:6504-6515. https://doi.org/10.3168/jds.2017-12583.

Cozzi, G., L. Ravarotto, F. Gottardo, A. L. Stefani, B. Contiero, L. Moro, M. Brscic, and P. Dalvit. 2011. Short communication: Reference values for blood parameters in Holstein dairy cows: Effects of parity, stage of lactation, and season of production. J. Dairy Sci. 94:3895-3901. https://doi.org/10.3168/jds.2010-3687.

Curone, G., J. Filipe, P. Cremonesi, E. Trevisi, M. Amadori, C. Pollera, B. Castiglioni, L. Turin, V. Tedde, D. Vigo, P. Moroni, A. Minuti, V. Bronzo, M. F. Addis, and F. Riva. 2018. What we have lost: Mastitis resistance in Holstein Friesians and in a local cattle breed. Res. Vet. Sci. 116:88-98. https://doi.org/10.1016/j .rvsc.2017.11.020

Drackley, J. K. 1999. Biology of dairy cows during the transition period: The final frontier? J. Dairy Sci. 82:2259-2273. https://doi .org/10.3168/jds.S0022-0302(99)75474-3.

Drackley, J. K., T. R. Overton, and G. N. Douglas. 2001. Adaptations of glucose and long-chain fatty acid metabolism in liver of dairy cows during the periparturient period. J. Dairy Sci. 84:E100-E112. https://doi.org/10.3168/jds.S0022-0302(01)70204-4.

Dubuc, J., T. F. Duffield, K. E. Leslie, J. S. Walton, and S. J. LeBlanc. 2010. Risk factors for postpartum uterine diseases in dairy cows. J Dairy Sci. 93:5764-5771. https://doi.org/10.3168/jds.2010-3429.

Duffield, T. F., K. D. Lissemore, B. W. McBride, and K. E. Leslie. 2009. Impact of hyperketonemia in early lactation dairy cows on health and production. J. Dairy Sci. 92:571-580. https://doi.org/ 10.3168/jds.2008-1507.

Erskine, R. J., and P. C. Bartlett. 1993. Serum concentrations of copper, iron, and zinc during Escherichia coli-induced mastitis. J. Dairy Sci. 76:408-413. https://doi.org/10.3168/jds.S0022 -0302(93)77360-9.

Ferré, N., J. Camps, E. Prats, E. Vilella, A. Paul, L. Figuera, and J. Joven. 2002. Serum paraoxonase activity: A new additional test for the improved evaluation of chronic liver damage. Clin. Chem. 48:261-268

Frei, B., R. Stocker, and B. N. Ames. 1988. Antioxidant defenses and lipid peroxidation in human blood plasma. Proc. Natl. Acad. Sci. USA 85:9748-9752. https://doi.org/10.1073/pnas.85.24.9748.

Grummer, R. R. 1995. Impact of changes in organic nutrient metabolism on feeding the transition dairy cow. J. Anim. Sci. 73:28202833.

Hanasand, M., R. Omdal, K. B. Norheim, L. G. Gøransson, C. Brede, and G. Jonsson. 2012. Improved detection of advanced oxidation protein products in plasma. Clin. Chim. Acta 413:901-906. https: //doi.org/10.1016/j.cca.2012.01.038.

Hartung, T., W. D. Docke, F. Gantner, G. Krieger, A. Sauer, P. Stevens, H. D. Volk, and A. Wendel. 1995. Effect of granulocyte colony-stimulating factor treatment on ex vivo blood cytokine response in human volunteers. Blood 85:2482-2489.

Hassfurther, R. L., T. N. Terhune, and P. C. Canning. 2015. Efficacy of polyethylene glycol-conjugated bovine granulocyte colony-stimulating factor for reducing the incidence of naturally occurring clinical mastitis in periparturient dairy cows and heifers. Am. J. Vet. Res. 76:231-238. https://doi.org/10.2460/ajvr.76.3.231.

Heinrich, P. C., I. Behrmann, S. Haan, H. M. Hermanns, G. MüllerNewen, and F. Schaper. 2003. Principles of interleukin (IL)-6-type cytokine signalling and its regulation. Biochem. J. 374:1-20. https: //doi.org/10.1042/BJ20030407. 
Hercus, T. R., D. Thomas, M. A. Guthridge, P. G. Ekert, J. KingScott, M. W. Parker, and A. F. Lopez. 2009. The granulocytemacrophage colony-stimulating factor receptor: Linking its structure to cell signaling and its role in disease. Blood 114:1289-1298. https://doi.org/10.1182/blood-2008-12-164004.

Ingvartsen, K. L., and K. Moyes. 2013. Nutrition, immune function and health of dairy cattle. Animal 7:112-122. https://doi.org/10 $.1017 /$ S175173111200170X.

Kehrli, M. E., J. P. Goff, M. G. Stevens, and T. C. Boone. 1991. Effects of granulocyte colony-stimulating factor administration to periparturient cows on neutrophils and bacterial shedding. J. Dairy Sci. 74:2448-2458. https://doi.org/10.3168/jds.S0022 -0302(91)78420-8.

Kehrli, M. E., B. J. Nonnecke, and J. A. Roth. 1989. Alterations in bovine neutrophil function during the periparturient period. Am. J. Vet. Res. 50:207-214. https://doi.org/10.1016/S0261 $-5177(02) 00005-5$.

Kimura, K., J. P. Goff, P. Canning, C. Wang, and J. A. Roth. 2014. Effect of recombinant bovine granulocyte colony-stimulating factor covalently bound to polyethylene glycol injection on neutrophil number and function in periparturient dairy cows. J. Dairy Sci. 97:4842-4851. https://doi.org/10.3168/jds.2013-7242.

Kimura, K., J. P. Goff, M. E. Kehrli, and T. A. Reinhardt. 2002. Decreased neutrophil function as a cause of retained placenta in dairy cattle. J. Dairy Sci. 85:544-550. https://doi.org/10.3168/jds .S0022-0302(02)74107-6.

Lohuis, J. A. C. M., W. Van Leeuwen, J. H. M. Verheijden, J. A. Smit, A. Brand, and A. S. J. P. A. M. Van Miert. 1988. Growth of Escherichia coli in whole and skim milk from endotoxin-induced mastitic quarters: In vitro effects of deferoxamine, zinc, and iron supplementation. J. Dairy Sci. 71:2772-2781. https://doi.org/10 .3168/jds.S0022-0302(88)79871-9.

Loor, J. J., M. Bionaz, and J. K. Drackley. 2013. Systems physiology in dairy cattle: Nutritional genomics and beyond. Annu. Rev. Anim. Biosci. 1:365-392. https://doi.org/10.1146/annurev-animal $-031412-103728$

McDougall, S., S. J. LeBlanc, and A. Heiser. 2017. Effect of prepartum energy balance on neutrophil function following pegbovigrastim treatment in periparturient cows. J. Dairy Sci. 100:7478-7492. https://doi.org/10.3168/jds.2017-12786.

Moran, L. K., J. Gutteridge, and G. Quinlan. 2001. Thiols in cellular redox signalling and control. Curr. Med. Chem. 8:763-772. https:/ /doi.org/10.2174/0929867013372904.

Moretti, P., S. Paltrinieri, E. Trevisi, M. Probo, A. Ferrari, A. Minuti, and A. Giordano. 2017. Reference intervals for hematological and biochemical parameters, acute phase proteins and markers of oxidation in Holstein dairy cows around 3 and 30 days after calving. Res. Vet. Sci. 114:322-331. https://doi.org/10.1016/j.rvsc.2017.06 .012 .

Nagata, S., and R. Fukunaga. 1991. Granulocyte colony-stimulating factor and its receptor. Prog. Growth Factor Res. 3:131-141. https: //doi.org/10.1016/S0955-2235(05)80004-3.

NRC. 2001. Nutrient Requirement Tables. 7th ed. Natl. Acad. Press, Washington, DC.

Osorio, J. S., E. Trevisi, P. Ji, J. K. Drackley, D. Luchini, G. Bertoni, and J. J. Loor. 2014. Biomarkers of inflammation, metabolism, and oxidative stress in blood, liver, and milk reveal a better immunometabolic status in peripartal cows supplemented with Smartamine M or MetaSmart. J. Dairy Sci. 97:7437-7450. https://doi .org/10.3168/jds.2013-7679.

Pires, J. A. A., C. Delavaud, Y. Faulconnier, D. Pomiès, and Y. Chilliard. 2013. Effects of body condition score at calving on indicators of fat and protein mobilization of periparturient Holstein-Friesian cows. J. Dairy Sci. 96:6423-6439. https://doi.org/10.3168/jds.2013 $-6801$.

Reynolds, C. K., P. C. Aikman, B. Lupoli, D. J. Humphries, and D. E. Beever. 2003. Splanchnic metabolism of dairy cows during the transition from late gestation through early lactation. J. Dairy Sci.
86:1201-1217. https://doi.org/10.3168/jds.S0022-0302(03)73704 $-7$.

Ruiz, R., L. O. Tedeschi, and A. Sepúlveda. 2017. Investigation of the effect of pegbovigrastim on some periparturient immune disorders and performance in Mexican dairy herds. J. Dairy Sci. 100:33053317. https://doi.org/10.3168/jds.2016-12003.

Russell, K. E., and A. J. Roussel. 2007. Evaluation of the Ruminant Serum Chemistry Profile. Vet. Clin. North Am. Food Anim. Pract. 23:403-426. https://doi.org/10.1016/j.cvfa.2007.07.003.

Sato, N., H. Mizukami, K. Tani, and S. Asano. 1991. Regulation of mRNA levels of alkaline phosphatase gene in neutrophilic granulocytes by granulocyte colony-stimulating factor and retinoic acid. Eur. J. Haematol. 46:107-111. https://doi.org/10.1111/j.1600 -0609.1991.tb00530.x.

Smith, B. P. 2014. Large animal internal medicine. Fifth ed. Mosby, Elsevier Health Sciences, St. Louis, MO.

Sordillo, L. M. 2016. Nutritional strategies to optimize dairy cattle immunity. J. Dairy Sci. 99:4967-4982. https://doi.org/10.3168/jds .2015-10354.

Soriani, M., D. Pietraforte, and M. Minetti. 1994. Antioxidant potential of anaerobic human plasma: Role of serum albumin and thiols as scavengers of carbon radicals. Arch. Biochem. Biophys. 312:180-188. https://doi.org/10.1006/abbi.1994.1297.

Trevisi, E., M. Amadori, S. Cogrossi, E. Razzuoli, and G. Bertoni. 2012a. Metabolic stress and inflammatory response in high-yielding, periparturient dairy cows. Res. Vet. Sci. 93:695-704. https:// doi.org/10.1016/j.rvsc.2011.11.008.

Trevisi, E., G. Bertoni, R. Lombardelli, and A. Minuti. 2013. Relation of inflammation and liver function with the plasma cortisol response to adrenocorticotropin in early lactating dairy cows. J. Dairy Sci. 96:5712-5722. https://doi.org/10.3168/jds.2012-6375.

Trevisi, E., P. Grossi, T. Bacchetti, G. Ferretti, and G. Bertoni. 2012b. Variation factors of paraoxonase in blood and in HDL lipoproteins in dairy cow. Prog. Nutr. 14:43-49.

Trevisi, E., N. Jahan, G. Bertoni, A. Ferrari, and A. Minuti. 2015. Pro-inflammatory cytokine profile in dairy cows: consequences for new lactation. Ital. J. Anim. Sci. 14. https://doi.org/10.4081/ijas .2015.3862.

Trevisi, E., and A. Minuti. 2018. Assessment of the innate immune response in the periparturient cow. Res. Vet. Sci. 116:47-54. https: //doi.org/10.1016/j.rvsc.2017.12.001.

Ueland, P. M., M. A. Mansoor, A. B. Guttormsen, F. Muller, P. Aukrust, H. Refsum, and A. M. Svardal. 1996. Reduced, oxidized and protein-bound forms of homocysteine and other aminothiols in plasma comprise the redox thiol status--a possible element of the extracellular antioxidant defense system. J. Nutr. 126:1281S1284S. https://doi.org/10.1093/jn/126.suppl_4.1281S.

Underwood, E. J., and N. F. Suttle. 1999. The Mineral Nutrition of Livestock. Third ed. CAB International, Wallingford, UK.

Urdl, M., L. Gruber, W. Obritzhauser, and A. Schauer. 2015. Metabolic parameters and their relationship to energy balance in multiparous Simmental, Brown Swiss and Holstein cows in the periparturient period as influenced by energy supply pre- and post-calving. J. Anim. Physiol. Anim. Nutr. (Berl.) 99:174-189. https://doi.org/ 10.1111/jpn.12178.

Veronese, F. M., and G. Pasut. 2005. PEGylation, successful approach to drug delivery. Drug Discov. Today 10:1451-1458. https://doi .org/10.1016/S1359-6446(05)03575-0.

Yang, B. B., P. K. Lum, M. M. Hayashi, and L. K. Roskos. 2004. Polyethylene glycol modification of filgrastim results in decreased renal clearance of the protein in rats. J. Pharm. Sci. 93:1367-1373. https://doi.org/10.1002/jps.20024.

Zinicola, M., H. Korzec, A. G. V. Teixeira, E. K. Ganda, L. Bringhenti, A. C. C. H. Tomazi, R. O. Gilbert, and R. C. Bicalho. 2018. Effects of pegbovigrastim administration on periparturient diseases, milk production, and reproductive performance of Holstein cows. J. Dairy Sci. 101:11199-11217. https://doi.org/10.3168/jds .2018-14869. 